\section{Pathophysiology Haemostasis and Thrombosis}

\title{
Adipose Tissue and Atherothrombosis
}

\author{
Marie-Christine Alessia, H. Roger Lijnen ${ }^{b}$, Delphine Bastelicaa, \\ Irene Juhan-Vague ${ }^{a}$ \\ aLaboratoire d'Hématologie, INSERM UMR626, UFR de Médecine, Université de la Méditerranée, Marseille, France \\ bCenter for Molecular and Vascular Biology, KU Leuven, Belgium
}

\section{Key Words}

Obesity · Leptin · Adiponectin · Inflammation · PAI-1 .

Thrombosis · Vascular

\begin{abstract}
Obesity is associated with increased cardiovascular mortality and morbidity mainly through insulin resistance. Dysregulation of protein secretion by adipose tissue is involved in obesity-related diseases. Adipose tissue contributes to create a subinflammatory status which could explain the disturbances in the haemostatic and fibrinolytic systems observed in obesity. Elevated plasma levels of PAI-1 demonstrated the strongest association with the degree of insulin resistance and could be an underlying mechanism for the thrombotic tendency and the progression of atherothrombosis during obesity. The effect of PAI-1 was examined on adipose tissue growth in several mouse models as well as on adipocyte differentiation in vitro. Most of the data indicate that PAI-1 can effectively modulate weight gain and may be a potential therapeutic target for controlling cardiovascular morbidity in obese subjects.
\end{abstract}

Copyright $@ 2004$ S. Karger AG, Basel

\section{KARGER}

Fax +4161306 1234

E-Mail: karger@karger.ch

www.karger.com
(C) 2004 S. Karger AG, Basel

1424-8832/04/0336-0290\$21.0/0

Accessible online at: www.krager.com/pht

\section{Introduction}

Obesity is associated with increased cardiovascular mortality and morbidity. Numerous observations suggest that biologically active molecules produced by adipose tissue constitute a critical link between obesity and cardiovascular complications. Adipose tissue controls energy metabolism, but also represents a secretory tissue for adipocytokines (leptin, adiponectin...) able to modify some vascular responses, for plasminogen activator inhibitor 1 (PAI-1) which favors fibrin accumulation and for proinflammatory cytokines. Here, we review new advances in our understanding of mechanisms which link adipose tissue to vascular risk. A particular focus is on PAI-1.

\section{Leptin}

Leptin is a glycoprotein produced by the mature adipocytes. It plays a key role in the control of body fat stores. During weight loss, its plasma level decreases and allows a positive feedback on food intake and anabolic pathways. Conversely, when adipose mass increases, plasma leptin concentration increases as well, leading to decreased appetite and increased energy expenditure.

However, despite high circulating levels of leptin, obese subjects remain obese and leptin administration only slight-

Marie-Christine ALESSI,

UMR 626, Faculté de Médecine Timone

27 Boulevard Jean Moulin

13385 Marseille cedex 5, France

Tel +33 491324 504; Fax: + 33491254 336;

E-mail: Marie-Christine.Alessi@medecine.univ-mrs.fr 
ly influences weight. These data have introduced the concept of leptin resistance. This resistance could affect, primarily, leptin's metabolic effects with preservation of the cardiovascular ones. Among the latter, leptin exerts a balanced effect on arterial pressure. Hypertensive effects of leptin appear predominantly due to sympathetic activation whereas several studies have suggested that leptin has a direct vascular effect that tends to decrease arterial pressure [1]. The leptin receptor belongs to the cytokine superfamily. Short length isoforms are expressed by endothelial cells where they could play a transport role [2]. The full receptor appears to mediate most of the biological effects of leptin. It is expressed in the aorta of mice [3] and could be involved in the action of leptin on the vascular tone and the calcification process which affects some vascular cells [3].

\section{Adiponectin}

Adiponectin is an adipocyte secreted protein that circulates in human plasma as different molecular weight complexes consisting of two to six trimers. Human studies demonstrated a positive correlation between adiponectin and insulin sensitivity levels. Its plasma concentration decreases with the degree of insulin resistance. This supports its negative association with body weight [4] and its increase after weight loss and thiazolinediones treatment. In mice, modulation of adiponectin was associated with that of the degree of insulin resistance suggesting a direct participation of adiponectin in development of the metabolic syndrome [5]. In Pima indians, high plasma adiponectin levels are associated with increased insulin sensitivity and reduced risk of type 2 diabetes [6]. This effect could involve two transmembrane receptors [7] and the AMP activated protein kinase [8] and, as recently proposed, a control of energy homeostasis through the central nervous system [9].

Adiponectin is now considered as an anti-atherosclerosis and anti-inflammatory adipokine. It is able to link types I, III and V collagens and to accumulate in an injured vessel wall [10] as well as in the myocardium after ischemic injury [11]. It decreases the expression of endothelial adhesion molecules such as VCAM-1 (vascular cell adhesion molecule-1) and ICAM-1 (intercellular adhesion molecule-1) [12]. Adiponectin suppresses macrophage-to-foam cell transformation [13], and inhibits Tumor necrosis factor (TNF) production [14]. It inhibits also oxidized low density lipoprotein-induced endothelial cell proliferation, suppresses cellular superoxide generation [15] and increases endothelial NO production [16].

These beneficial effects observed in vitro were confirmed in vivo. Apolipoprotein E-deficient mice treated with recombinant adenovirus expressing human adiponectin

Adipose Tissue and Atherothrombosis developped smaller lesions in aortic sinus than the control mice [17]. Conversely, adiponectin-deficient mice showed severe neointimal thickening and increased proliferation of vascular smooth muscle cells in injured arteries [18,19]. Discordant results have been published on the effects of adiponection on angiogenesis and apoptosis [20-22]. Patients with atherosclerosis exhibit low circulating adiponectin levels [23,24], and high plasma adiponectin concentrations are associated with lower risk of myocardial infarction. Interestingly this relationship can be only partly explained by differences in blood lipids and is independent of inflammation and glycemic status [25]. In addition, some single nucleotide polymorphisms in the adiponectin gene were reported to be associated with an increased risk of type 2 diabetes and coronary artery disease [26,27].

\section{Inflammatory Proteins}

Obesity is associated with inflammation; including elevated levels of fibrinogen, C-reactive protein (CRP) and interleukin-6 (IL6) [28]. Thiazolinediones decrease CRP levels [29] and chronic inflammation emerges as a new risk factor for the development of type 2 diabetes [30].The monocyte infiltration of the adipose tissue could be the basis of this inflammatory process [31]. Monocyte chemoattractant protein 1 (MCP-1) mRNA is overexpressed in the adipose tissue of genetically obese mice compared with wildtype littermates and in vitro studies suggest that MCP-1 may contribute to the development of insulin resistance and induces adipocyte dedifferentiation [32].

Inflammatory cytokines such as TNF and IL6 have been involved in the development of insulin resistance [33-35] mainly in mice. In humans, although the demonstration of an association between TNF and insulin resistance gave discrepant results [36-40], the circulating levels of TNF receptors appear closely associated with the degree of insulin resistance [41-43]. IL6 is produced by human adipose tissue [44] mainly by the visceral territory [45]. As for TNF, the association between circulating levels of IL6 and insulin resistance in man is controversial. Obesity, and not insulin resistance, often appears the major determinant of serum IL6 levels.

\section{Angiotensinogen}

The renin-angiotensin system is an important regulator of blood pressure, and blockade of this system improves blood pressure in obesity and type 2 diabetes. The components of the renin-angiotensin system are fully represented in the adipose tissue. A growing body of evidence supports

Pathophysiol Haemost Thromb 2003/2004;33:290-297 
the concept that alterations in adipocyte production of components of the renin-angiotensin system may contribute to disorders of the metabolic syndrome, including obesity and obesity-related hypertension, diabetes and atherosclerosis [46,47]. Results from genetically engineered mice overexpressing the angiotensinogen gene in adipose tissue support the concept that adipocyte-derived angiotensinogen can contribute to the circulating angiotensinogen concentration and modulate blood pressure [48]. Randomised controlled trials indicate that pharmacological renin-angiotensin system blockade improves insulin sensitivity and reduces the risk of type 2 diabetes. The concept that the local reninangiotensin system plays a role in body-fat storage and in lipid and carbohydrate metabolism in humans is further supported by genetic studies showing that susceptibility to weight gain is greater in individuals carrying certain reninangiotensin system allelic variants [49].

\section{Resistin [50]}

Resistin is secreted by adipose tissue. Whereas in mice modulation of resistin influences the insulin sensitivity, data obtained in humans are controversial. Resistin exerts some vascular effects. It induces the expression of endothelial adhesion molecules such as VCAM-1 and ICAM-1 [51,52], the endothelial production of endothelin 1 and the expression of CD40 ligand.

\section{PAI-1}

PAI-1 is a serpin which major function is to limit plasminogen activation and impair fibrinolysis. It occurs in plasma and tissues. Experimental data in mice have emphasised the role of PAI-1 in the development of thrombosis in vivo in the venous [53-56] and the arterial territories [57-61]. Data on the effect of PAI-1 on the development of atherosclerosis in mice [62-64] and on the influence of PAI-1 on the wound healing response to arterial injury [65-70] are sometimes contradictory mainly due to different degrees of thrombosis induced in the experimental models.

In patients, the between-person variability of fibrinolytic activity is unlikely to be an important risk factor for venous thrombosis in the general population [71]. In contrast, there are clinical evidences for an association between increased PAI-1 levels and myocardial infarction. It was shown that the acute release of PAI-1 in patients with STsegment elevation myocardial infarction (difference between PAI at admission and 24 hours later) was dramatically higher in patients who died than in those who survived. Postangioplasty TIMI-3 flow and the acute release of PAI-1 were the only two independent predictors of death at 30 days [72]. Plasma concentrations of fibrinolytic factors in the subacute phase of myocardial infarction predict recurrent myocardial infarction or sudden cardiac death [73]. In large epidemiological studies, elevated plasma PAI-1 levels have been identified as a predictor of cardiovascular risk [74-78]. Co-exposure to high plasma PAI-1 activity and smoking synergistically interacts to predict myocardial infarction in men [79]. Post procedural plasma PAI-1 has also been implicated in the risk of restenosis after percutaneous coronary angioplasty. Most of the studies have described a deleterious effect of high plasma PAI-1 levels which may predict restenosis [80-84]. The same effect was obtained in a group of 251 consecutive patients who underwent femoro-popliteal percutaneous transluminal angioplasty [85]. However, in two studies decreased PAI-1 antigen (and not increased) levels exhibited a high predictive power of deleterious events $[86,87]$.

In contrast to the association observed between plasma PAI-1 levels and the risk of an acute vascular event, the demonstration of an association between plasma PAI-1 and the degree of atherosclerosis is less evident. Significant upregulation of PAI-1 in the vessel wall was demonstrated in human atherosclerotic plaques [88-90]. Sobel et al [91] and Pandolfi et al [92] have provided evidence that type II diabetes is associated with an increased PAI-1 expression in arterial wall. In the Danish Glostrup study including 325 men and 370 women of 60 years, subjects with high Intima Media Thickness (IMT) had higher CRP but not PAI-1 levels. Association between fibrinogen and D-dimer but not PAI-1 concentrations and number of plaques was observed [93]. However, in a population of 200 subjects, multivariate logistic regression analysis confirmed the associations between greater than normal mean IMT and plasma concentrations of LDL cholesterol and PAI-1 as well as total ultrasonographic score [94]. These discrepancies could be related to the variables controlled for. Indeed, Folsom et al showed that adjustment for lifestyle and medical covariates essentially eliminated these associations suggesting that PAI-1 may partly mediate the effects of other risk factors on carotid atherosclerosis [95].

The increased PAI-1 expression in patients prone to acute vascular events has been related to several mechanisms. PAI-1 is known to be upregulated by several inflammatory cytokines such as TNF and Transforming Growth Factor beta (TGF- $\beta$ ). Thus, the healing process which accompanies atherosclerosis could explain the upregulation of PAI-1 in this pathology. A strong relationship between activation of the renin-angiotensin-aldosterone system (RAAS) and plasma PAI-1 [96] has also been described, and increased PAI-1 may represent a circulating marker of activation of the RAAS that may be indirectly related to infarct 
size. Interestingly, PAI-1 has been shown to predict myocardial events in univariate analysis but the predictive power was not affected by adjustement for inflammatory parameters and disappeared after adjustment for Body Mass Index (BMI) , triglycerides and and High Density Lipoprotein (HDL) cholesterol, markers of the metabolic syndrome (MS) [97]. This suggests that the metabolic syndrome is a prerogative to high plasma PAI-1 levels in patients prone to atherosclerosis.

The MS consists of a cluster of metabolic abnormalities, which includes obesity with a distribution of the fat in the central part of the body (visceral or android obesity), impaired glucose tolerance, hyperinsulinaemia, dyslipidaemia with elevated triglycerides, low HDL cholesterol concentration, increased proportion of small dense lipoparticles, and hypertension [98]. Recently, more components of this syndrome have been proposed, including subclinical inflammation, hyperuricaemia and microalbuminuria. Furthermore, haemostatic abnormalities, with increased PAI-1 levels, are also a core feature of the MS [99]. Paradoxically, the observed metabolic disturbances are similar to those observed during lipodystrophy and could be the witness of a deficiency in the peripheral fat storage process leading to a redistribution of fat in "lean tissues" such as visceral tissues (mainly the liver) causing lipotoxicity.

The link between PAI-1 and the MS was established many years ago. During the last decade, strong associations between plasma PAI-1 levels and parameters of the MS were repeatedly shown [for review see 100]. Interventional studies have provided data that by improving insulin resistance, plasma PAI-1 levels decrease [101-103].

Most of the predictive power of PAI-1 for cardiovascular events depends on the MS. The ECAT study has shown that the prognostic value of PAI-1 in predicting coronary events is related principally to insulin resistance [97]. The mechanisms involved in increased PAI-1 production in the MS are not completely explained and the origin of PAI-1 is also uncertain. Obviously, induction of PAI-1 overexpression in the MS is a complex process and it is possible that several inducers are involved at the same time as well as at several sites of synthesis. Many of the metabolic parameters, which are disturbed in the MS, induce PAI-1 synthesis in different cultured cell lines [for review see 104]. Human adipose tissue, abundant in the MS, has attracted considerable attention as a possible source of PAI-1. Indeed, PAI-1 is synthesised in human adipose tissue proportionally to the BMI [for review see 104] . Visceral fat produces more PAI1 than subcutaneous abdominal fat and subcutaneous femoral fat produces less PAI-1 than the latter [105] suggesting that visceral tissue, a core feature of the MS, could be a potential source of PAI-1. Fat accumulation in the liver is also a common feature of the MS. Some clinical evidence

Adipose Tissue and Atherothrombosis has been provided that steatotic liver or the mechanisms leading to liver steatohepatitis may be involved in increased PAI-1 expression in the MS [106]. Liver steatohepatitis might be important also in conditions where insulin resistance is not accompanied with obesity, but in spite of it, plasma PAI-1 levels are elevated (i.e. in patients with lipodys(a)trophy). This leads to the assumption that increased plasma PAI-1 levels during obesity may reflect the ectopic fat storage process (visceral fat, liver steatosis..) which is associated with the MS.

Evidence has emerged that the TNF pathway plays a particular role in PAI-1 overexpression in the MS. In ob/ob mice, the inhibition of TNF with neutralising antibodies or deletion of TNF receptors (RI and RII), leads to significant reduction of plasma PAI-1 levels and adipose tissue PAI-1 expression [107]. On the other hand, parallel increases in TNFRI and PAI-1 in adipose tissue or plasma indicate that this receptor may be involved in the induction of PAI-1 synthesis during the MS [108]. TGF- $\beta$, a multifunctional cytokine which regulates cells growth and differentiation, could also be involved in the regulation of PAI-1 during insulin resistance [109] .

The demonstration that PAI-1 levels predicted diabetes independently from other known risk factors [110] as well as the involvement of PAI-1 in tissue remodelling has led to speculate that the increased expression of PAI- 1 in obesity influences the remodelling and expansion of the adipose tissue and the course of the metabolic syndrome. Recent experiments in animal models elucidated this issue partly.

Three studies in mice have examined the role of PAI-1 deficiency in weight gain. Two of them, a genetically and a nutritionally model of induced obesity demonstrated that PAI-1 deficient mice developed less obesity and concomitantly less insulin resistance and that downregulation of PAI-1 by an angiotensin type 1 receptor antagonist in wild type mice ameliorated diet-induced obesity [111,112]. The third study did not induce strong adiposity changes [113]. Furthermore, PAI-1 transgenic mice, which overexpress PAI-1 in adipose tissue, gained weight slower than their wild-type controls and developed hyperinsulinaemia [114]. From these experiments it could be proposed that increased plasma PAI-1 levels observed in patients during the MS could represent an induced counter-regulatory mechanism to limit excessive adiposity. This needs however further confirmation.

\section{Conclusion}

There is now evidence that adipose tissue may have a strong impact on most obesity related complications. A clustering between insulin resistance, adipocyte secreted protein, hypofibrinolysis, inflammation, thrombosis and ather-

Pathophysiol Haemost Thromb 2003/2004;33:290-297 
osclerosis becomes more and more evident, but also renders the situation more and more complex with numerous possible feedback loops.

Further efforts with experimental and clinical studies are needed to better understand this complex interplay. Nevertheless, it is tempting to propose that adiponectin,
PAI-1 represent interesting targets for therapeutic intervention that aim to decrease the risk of both: type 2 diabetes and cardiovascular diseases.

\section{References}

1 Rahmouni K, Haynes WG. Leptin and the cardiovascular system. Recent Prog Horm Res 2004;59:225-244.

- 2 Bjorbaek C, Elmquist JK, Michl P, Ahima RS, van Bueren A, McCall AL, Flier JS. Expression of leptin receptor isoforms in rat brain microvessels. Endocrinology 1998;139:3485-3491.

3 Parhami F, Tintut Y, Ballard A, Fogelman AM, Demer LL. Leptin enhances the calcification of vascular cells: artery wall as a target of leptin. Circ Res 2001;88:954-960.

4 Weyer C, Funahashi T, Tanaka S, et al. Hypoadiponectinemia in obesity and type 2 diabetes : close association with insulin resistance and hyperinsulinemia. J Clin Endocrinol Metab 2001;86:1930-1935.

${ }_{5}$ Yamauchi T, Kamon J, Waki H, Terauchi Y, Kubota N, Hara K, Mori Y, Ide T, Murakami K, Tsuboyama-Kasaoka N, Ezaki O, Akanuma Y, Gavrilova O, Vinson C, Reitman ML, Kagechika H, Shudo K, Yoda M, Nakano Y, Tobe K, Nagai R, Kimura S, Tomita M, Froguel P, Kadowaki T. The fat-derived hormone adiponectin reverses insulin resistance associated with both lipoatrophy and obesity. Nat Med 2001;7:941-946.

6 Lindsay RS, Funahashi T, Hanson RL, Matsuzawa Y, Tanaka S, Tataranni PA, Knowler WC, Krakoff J. Adiponectin and development of type 2 diabetes in the Pima Indian population. Lancet 2002 6;360:57-58.

7 Yamauchi T, Kamon J, Ito Y, Tsuchida A, Yokomizo T, Kita S, Sugiyama T, Miyagishi M, Hara K, Tsunoda M, Murakami K, Ohteki T, Uchida S, Takekawa S, Waki H, Tsuno NH, Shibata Y, Terauchi Y, Froguel P, Tobe K, Koyasu S, Taira K, Kitamura T, Shimizu T, Nagai R, Kadowaki T. Cloning of adiponectin receptors that mediate antidiabetic metabolic effects. Nature 2003;423:762-769.

8 Wu X, Motoshima H, Mahadev K, Stalker TJ, Scalia R, Goldstein BJ. Involvement of AMP-activated protein kinase in glucose uptake stimulated by the globular domain of adiponectin in primary rat adipocytes. Diabetes. 2003;52:1355-1363.

9 Qi Y, Takahashi N, Hileman SM, Patel HR, Berg AH, Pajvani UB, Scherer PE, Ahima RS. Adiponectin acts in the brain to decrease body weight. Nat Med 2004;10:524-529.

10 Okamoto Y, Arita Y, Nishida M, Muraguchi M, Ouchi N, Takahashi M, Igura T, Inui Y, Kihara S, Nakamura T, Yamashita S, Miyagawa J, Funahashi T, Matsuzawa Y. An adipocyte-derived plasma protein, adiponectin, adheres to injured vascular walls. Horm Metab Res 2000;32:47-50.
Ishikawa Y, Akasaka Y, Ishii T, Yoda-Murakami M, Choi-Miura NH, Tomita M, Ito K, Zhang L, Akishima Y, Ishihara M, Muramatsu M, Taniyama M. Changes in the distribution pattern of gelatinbinding protein of $28 \mathrm{kDa}$ (adiponectin) in myocardial remodelling after ischaemic injury. Histopathology 2003;42:43-52.

12 Ouchi N, Kihara S, Arita Y, et al. Adiponectin, an adipocyte-derived plasma protein, inhibits endothelial NF-kappaB signaling through a cAMP-dependent pathway. Circulation 2000;102: 1296-1301.

13 Ouchi N, Kihara S, Arita Y, et al. Adipocytederived plasma protein, adiponectin, suppresses lipid accumulation and class A scavenger receptor expression in human monocyte-derived macrophages. Circulation 2001;103:1057-1063

14 Yokota T, Oritani K, Takahashi I, et al. Adiponectin, a new member of the family of soluble defense collagens, negatively regulates the growth of myelomonocytic progenitors and the functions of macrophages. Blood 2000;96:17231732.

15 Motoshima H, Wu X, Mahadev K, Goldstein BJ. Adiponectin suppresses proliferation and superoxide generation and enhances eNOS activity in endothelial cells treated with oxidized LDL. Biochem Biophys Res Commun 2004;315:264271.

16 Hattori Y, Suzuki M, Hattori S, Kasai K. Globula adiponectin upregulates nitric oxide production in vascular endothelial cells. Diabetologia 2003 ;46:1543-1549.

17 Okamoto Y, Kihara S, Ouchi N, Nishida M, Arita Y, Kumada M, Ohashi K, Sakai N, Shimomura I, Kobayashi H, Terasaka N, Inaba T, Funahashi T, Matsuzawa Y. Adiponectin reduces atherosclerosis in apolipoprotein E-deficient mice. Circulation 2002;106:2767-2770.

18 Matsuda M, Shimomura I, Sata M, Arita Y, Nishida M, Maeda N, Kumada M, Okamoto Y, Nagaretani H, Nishizawa H, Kishida K, Komuro R, Ouchi N, Kihara S, Nagai R, Funahashi T, Matsuzawa Y. Role of adiponectin in preventing vascular stenosis. The missing link of adipo-vascular axis. J Biol Chem. 2002;277:37487-37491.

19 Kubota N, Terauchi Y, Yamauchi T, Kubota T, Moroi M, Matsui J, Eto K, Yamashita T, Kamon J, Satoh H, Yano W, Froguel P, Nagai R, Kimura S, Kadowaki T, Noda T. Disruption of adiponectin causes insulin resistance and neointimal formation. J Biol Chem 2002;277:25863-25866.
20 Ouchi N, Kobayashi H, Kihara S, Kumada M, Sato K, Inoue $\mathrm{T}$, Funahashi $\mathrm{T}$, Walsh $\mathrm{K}$. Adiponectin stimulates angiogenesis by promoting cross-talk between AMP-activated protein kinase and Akt signaling in endothelial cells. J Biol Chem 2004;279:1304-1309.

21 Kobayashi H, Ouchi N, Kihara S, Walsh K, Kumada M, Abe Y, Funahashi T, Matsuzawa Y. Selective suppression of endothelial cell apoptosis by the high molecular weight form of adiponectin. Circ Res 2004;94:e27-31.

22 Brakenhielm E, Veitonmaki N, Cao R, Kihara S, Matsuzawa Y, Zhivotovsky B, Funahashi T, Cao Y. Adiponectin-induced antiangiogenesis and antitumor activity involve caspase-mediated endothelial cell apoptosis. Proc Natl Acad Sci USA 2004;101:2476-2481.

23 Nakamura Y, Shimada K, Fukuda D, Shimada Y, Ehara S, Hirose M, Kataoka T, Kamimori K, Shimodozono S, Kobayashi Y, Yoshiyama M, Takeuchi K, Yoshikawa J. Implications of plasma concentrations of adiponectin in patients with coronary artery disease. Heart 2004;90:528-533.

24 Kojima S, Funahashi T, Sakamoto T, Miyamoto S, Soejima H, Hokamaki J, Kajiwara I, Sugiyama S, Yoshimura M, Fujimoto K, Miyao Y, Suefuji H, Kitagawa A, Ouchi N, Kihara S, Matsuzawa Y, Ogawa $\mathrm{H}$. The variation of plasma concentrations of a novel, adipocyte derived protein, adiponectin, in patients with acute myocardial infarction. Heart 2003;89:667.

25 Pischon T, Girman CJ, Hotamisligil GS, Rifai N, $\mathrm{Hu}$ FB, Rimm EB. Plasma adiponectin levels and risk of myocardial infarction in men. JAMA 2004;291:1730-1737.

26 Ohashi K, Ouchi N, Kihara S, Funahashi T, Nakamura T, Sumitsuji S, Kawamoto T, Matsumoto S, Nagaretani H, Kumada M, Okamoto Y, Nishizawa H, Kishida K, Maeda N, Hiraoka H, Iwashima Y, Ishikawa K, Ohishi M, Katsuya T, Rakugi H, Ogihara T, Matsuzawa Y. Adiponectin I164T mutation is associated with the metabolic syndrome and coronary artery disease. J Am Coll Cardiol 2004;43:1195-1200.

27 Fumeron F, Aubert R, Siddiq A, Betoulle D, Pean F, Hadjadj S, Tichet J, Wilpart E, Chesnier MC, Balkau B, Froguel P, Marre M; Epidemiologic Data on the Insulin Resistance Syndrome (DESIR) Study Group. Adiponectin gene polymorphisms and adiponectin levels are independently associated with the development of hyperglycemia during a 3-year period: the epidemiologic data on the insulin resistance syndrome prospective study. Diabetes 2004;53:1150-1157. 
28 Yudkin JS. Adipose tissue, insulin action and vascular disease: inflammatory signals. Int $\mathrm{J}$ Obes Relat Metab Disord 2003;27:S25-28.

29 Sidhu JS, Cowan D, Kaski JC. The effects of rosiglitazone, a peroxisome proliferator-activated receptor-gamma agonist, on markers of endothelial cell activation, C-reactive protein, and fibrinogen levels in non-diabetic coronary artery disease patients. J Am Coll Cardiol 2003;42:1757-1763.

30 Festa A, D'Agostino R Jr, Tracy RP, Haffner SM. $\mathrm{C}$-reactive protein is more strongly related to postglucose load glucose than to fasting glucose in non-diabetic subjects; the Insulin Resistance Atherosclerosis Study. Diabet Med 2002;19:939943.

31 Curat CA, Miranville A, Sengenes C, Diehl M, Tonus C, Busse R, Bouloumie A. From Blood Monocytes to Adipose Tissue-Resident Macrophages: Induction of Diapedesis by Human Mature Adipocytes. Diabetes 2004;53:1285-1292.

32 Sartipy P, Loskutoff DJ. Monocyte chemoattractant protein 1 in obesity and insulin resistance Proc Natl Acad Sci USA 2003;100:7265-7270.

33 Warne JP. Tumour necrosis factor alpha: a key regulator of adipose tissue mass. J Endocrinol 2003;177:351-355.

34 Wallenius V, Wallenius K, Ahren B, Rudling M, Carlsten H, Dickson SL, Ohlsson C, Jansson JO. Interleukin-6-deficient mice develop mature-onset obesity. Nat Med 2002;8:75-79

35 Rotter V, Nagaev I, Smith U. Interleukin-6 (IL-6) induces insulin resistance in 3T3-L1 adipocytes and is, like IL-8 and tumor necrosis factor-alpha, overexpressed in human fat cells from insulinresistant subjects. J Biol Chem 2003;278:4577745784.

36 Zavaroni I, Numeroso F, Dongiovanni P, Ardigo D, Valenti L, Fracanzani A, Valtuena S, Delsignore $\mathrm{R}$, Fargion S, Reaven GM. What is the contribution of differences in three measures of tumor necrosis factor-alpha activity to insulin resistance in healthy volunteers? Metabolism 2003;52:15931596

37 Winkler G, Kiss S, Keszthelyi L, Sapi Z, Ory I, Salamon F, Kovacs M, Vargha P, Szekeres O, Speer G, Karadi I, Sikter M, Kaszas E, Dworak O, Gero G, Cseh K. Expression of tumor necrosis factor (TNF)-alpha protein in the subcutaneous and visceral adipose tissue in correlation with adipocyte cell volume, serum TNF-alpha, soluble serum TNF-receptor-2 concentrations and C-peptide level. Eur J Endocrinol 2003;149:129-135

-38 Bruun JM, Verdich C, Toubro S, Astrup A, Richelsen B. Association between measures of insulin sensitivity and circulating levels of interleukin-8, interleukin-6 and tumor necrosis factoralpha. Effect of weight loss in obese men. Eur J Endocrinol 2003;148:535-542

39 Demirbas B, Guler S, Cakir B, Culha C, Aral Y. Plasma tumor necrosis factor-alpha levels and insulin resistance in nondiabetic hypertensive subjects. Horm Res 2002;58:283-286

40 Jovinge S, Hamsten A, Tornvall P, Proudler A, Bavenholm P, Ericsson CG, Godsland I, de Faire U, Nilsson J. Evidence for a role of tumor necrosis factor alpha in disturbances of triglyceride and glucose metabolism predisposing to coronary heart disease. Metabolism 1998;47:113-118

41 Straczkowski M, Kowalska I, Stepien A, DzienisStraczkowska S, Szelachowska M, Kinalska I. Increased plasma-soluble tumor necrosis factoralpha receptor 2 level in lean nondiabetic offspring of type 2 diabetic subjects. Diabetes Care 2002;25:1824-1828
42 Dzienis-Straczkowska S, Straczkowski M, Szelachowska M, Stepien A, Kowalska I, Kinalska I. Soluble tumor necrosis factor-alpha receptors in young obese subjects with normal and impaired glucose tolerance. Diabetes Care 2003;26:875-880

43 Chu NF, Chang JB, Shieh SM. Plasma leptin, fatty acids, and tumor necrosis factor-receptor and insulin resistance in children. Obes Res 2003;11:532-540

44 Mohamed-Ali V, Goodrick S, Rawesh A, Katz DR, Miles JM, Yudkin JS, Klein S, Coppack SW. Subcutaneous adipose tissue releases interleukin6, but not tumor necrosis factor-alpha, in vivo. J Clin Endocrinol Metab 1997;82:4196-4200

45 Fain JN, Madan AK, Hiler ML, Cheema P, Bahouth SW. Comparison of the release of adipokines by adipose tissue, adipose tissue matrix, and adipocytes from visceral and subcutaneous abdominal adipose tissues of obese humans. Endocrinology 2004;145:2273-2282.

46 Goossens GH, Blaak EE, van Baak MA. Possible involvement of the adipose tissue reninangiotensin system in the pathophysiology of obesity and obesity-related disorders. Obes Rev 2003;4:43-55

47 Engeli S, Schling P, Gorzelniak K, Boschmann M, Janke J, Ailhaud G, Teboul M, Massiera F, Sharma AM The adipose-tissue renin-angiotensin-aldosterone system: role in the metabolic syndrome? Int J Biochem Cell Biol 2003;35:807-825

48 Massiera F, Bloch-Faure M, Ceiler D, Murakami K, Fukamizu A, Gasc 16JM, Quignard-Boulange A, Negrel R, Ailhaud G, Seydoux J, Meneton P, Teboul M Adipose angiotensinogen is involved in adipose tissue growth and blood pressure regulation. FASEB J 2001;15:2727-2729

49 Strazzullo P, Iacone R, Iacoviello L, Russo O, Barba G, Russo P, D'Orazio A, Barbato A, Cappuccio FP, Farinaro E, Siani A; Olivetti Prospective Heart Study. Genetic variation in the renin-angiotensin system and abdominal adiposity in men: the Olivetti Prospective Heart Study. Ann Intern Med 2003;138:17-23

50 Steppan CM, Lazar MA. The current biology of resistin. J Intern Med 2004;255:439-447.

51 Verma S, Li SH, Wang CH, Fedak PW, Li RK, Weisel RD, Mickle DA. Resistin promotes endothelial cell activation: further evidence of adipokine-endothelial interaction. Circulation 2003;108:736-740.

52 Kawanami D, Maemura K, Takeda N, Harada T, Nojiri T, Imai Y, Manabe I, Utsunomiya K, Nagai R. Direct reciprocal effects of resistin and adiponectin on vascular endothelial cells: a new insight into adipocytokine-endothelial cell interactions. Biochem Biophys Res Commun 2004;314:415-419.

53 Montes R, Declerck PJ, Calvo A, Montes M, Hermida J, Munoz MC, Rocha E. Prevention of renal fibrin deposition in endotoxin-induced DIC through inhibition of PAI-1. Thromb Haemost 2000;84:65-70

54 Erickson LA, Fici GJ, Lund JE, Boyle TP, Polites HG, Marotti KR. Development of venous occlusions in mice transgenic for the plasminogen activator inhibitor-1 gene. Nature 1990;346:74-76.

55 Vaughan DE, Declerck PJ, Van Houtte E, De Mo $\mathrm{M}$, Collen D. Reactivated recombinant plasminogen activator inhibitor-1 (rPAI-1) effectively prevents thrombolysis in vivo. Thromb Haemost 1992;68:60-63.
56 Friederich PW, Levi M, Biemond BJ, Charlton P, Templeton D, van Zonneveld AJ, Bevan P, Pannekoek H, Ten Cate JW. Novel low-molecularweight inhibitor of PAI-1 (XR5118) promotes endogenous fibrinolysis and reduces postthrombolysis thrombus growth in rabbits. Circulation 1997;96:916-921.

57 Farrehi PM, Ozaki CK, Carmeliet P, Fay WP. Regulation of arterial thrombolysis by plasminogen activator inhibitor-1 in mice. Circulation 1998;97:1002-1008

58 Eitzman DT, Westrick RJ, Nabel EG, Ginsburg D. Plasminogen activator inhibitor-1 and vitronectin promote vascular thrombosis in mice. Blood 2000;95:577-580.

59 Konstantinides S, Schafer K, Loskutoff DJ. Do PAI-1 and vitronectin promote or inhibit neointima formation? The exact role of the fibrinolytic system in vascular remodeling remains uncertain. Arterioscler Thromb Vasc Biol 2002;22:19431955.

60 Takeshita K, Yamamoto K, Ito M, Kondo T, Matsushita T, Hirai M, Kojima T, Nishimura M, Nabeshima Y, Loskutoff DJ, Saito H, Murohara T. Increased expression of plasminogen activator inhibitor-1 with fibrin deposition in a murine model of aging, "Klotho" mouse. Semin Thromb Hemost 2002;28:545-554.

61 Eren M, Painter CA, Atkinson JB, Declerck PJ, Vaughan DE. Age-dependent spontaneous coronary arterial thrombosis in transgenic mice that express a stable form of human plasminogen activator inhibitor-1. Circulation 2002;106:491-496.

-62 Sjoland H, Eitzman DT, Gordon D, Westrick RJ, Nabel EG, Ginsburg D. Atherosclerosis progression in LDL receptor deficient and apolipoprotein Edeficient mice is independent of genetic alterations in plasminogen activator inhibitor-1. Arterioscler Thromb Vasc Biol 2000;20:846-852.

63 Eitzman DT, Westrick RJ, Xu Z, Tyson J, Ginsburg D. Plasminogen activatorinhibitor-1 deficiency protects against atherosclerosis progression in the mousecarotid artery. Blood 2000;96:4212-4215.

64 Luttun A, Lupu F, Storkebaum E, Hoylaerts MF, Moons L, Crawley J, Bono F,Poole AR, Tipping P, Herbert J-M, Collen D, Carmeliet P. Lack of plasminogen activator inhibitor-1 promotes growth and abnormal matrix remodeling of advanced atherosclerotic plaques in apolipoprotein E-deficient mice. Arterioscler Thromb Vasc Biol 2002;22:499-505.

65 DeYoung MB, Tom C, Dichek DA. Plasminogen activator inhibitor type 1 increases neointima formation in balloon-injured rat carotid arteries. Circulation 2001;104:1972-191.

66 Zhu Y, Farrehi PM, Fay WP. Plasminogen activator inhibitor type 1 enhances neointima formation after oxidative vascular injury in atherosclerosisprone mice. Circulation 2001;103:3105-3110.

67 Ploplis VA, Cornelissen I, Sandoval-Cooper MJ, Weeks L, Noria FA, Castellino FJ. Remodeling of the vessel wall after copper-induced injury is highly attenuated in mice with a total deficiency of plasminogen activator inhibitor-1. Am J Pathol 2001;158:107-117.

68 Carmeliet P, Moons L, Lijnen R, Janssens S, Lupu F, Collen D, Gerard RD. Inhibitory role of plasminogen activator inhibitor-1 in arterial wound healing and neointima formation: a gene targeting and gene transfer study in mice. Circulation 1997; 96:3180-3191. 
69 De Waard V, Arkenbout EK, Carmeliet P, Lindner V, Pannekoek H. Plasminogen activator inhibitor 1 and vitronectin protect against stenosis in a murine carotid artery ligation model. Arterioscler Thromb Vasc Biol 2002;22:1978-1983.

70 Peng L, Bhatia N, Parker AC, Zhu Y, Fay WP. Endogenous vitronectin and plasminogen activator inhibitor-1 promote neointima formation in murine carotid arteries. Arterioscler Thromb Vasc Biol 2002;22:934-939.

71 Folsom AR, Cushman M, Heckbert SR, Rosamond WD, Aleksic N. Prospective study of fibrinolytic markers and venous thromboembolism. J Clin Epidemiol 2003;56:598-603.

72 Collet JP, Montalescot G, Vicaut E, Ankri A, Walylo F, Lesty C, Choussat R, Beygui F, Borentain M, Vignolles N, Thomas D. Acute release of plasminogen activator inhibitor-1 in STsegment elevation myocardial infarction predicts mortality. Circulation 2003;108:391-394.

73 Soeki T, Tamura Y, Shinohara H, Sakabe K, Onose Y, Fukuda N. Plasma concentrations of fibrinolytic factors in the subacute phase of myocardial infarction predict recurrent myocardial infarction or sudden cardiac death. Int $\mathrm{J}$ Cardiol 2002;85:277-283.

74 Hamsten A, de Faire U, Walldius G, Dahlen G, Szamosi A, Landou C, et al. Plasminogen activator inhibitor in plasma : Risk factor for recurrent myocardial infarction. Lancet 1987;2:3-9.

75 Juhan-Vague I, Pyke SDM, Alessi MC, Jespersen J, Haverkate F, Thompson SG. Fibrinolytic factors and the risk of myocardial infarction or sudden death in patients with angina pectoris. Circulation 1996;94:2057-2063.

76 Anand SS, Yi Q, Gerstein H, Lonn E, Jacobs R, Vuksan V, Teo K, Davis B, Montague P, Yusuf S. Study of Health Assessment and Risk in Ethnic Groups ; Study of Health Assessment and Risk Evaluation in Aboriginal Peoples Investigators. Relationship of metabolic syndrome and fibrinolytic dysfunction to cardiovascular disease. Circulation 2003;108:420-425.

77 Thogersen AM, Jansson JH, Boman K, Nilsson TK, Weinehall L, Huhtasaari F, Hallmans G. High plasminogen activator inhibitor and tissue plasminogen activator levels in plasma precede a first acute myocardial infarction in both men and women: evidence for the fibrinolytic system as an independent primary risk factor. Circulation 1998; 98:2241-2247.

78 Sobel BE, Woodcock-Mitchell J, Schneider DJ, Holt RE, Marutsuka K, Gold H. Increased plasminogen activator inhibitor type 1 in coronary artery atherectomy specimens from type 2 diabetic compared with nondiabetic patients: a potential factor predisposing to thrombosis and its persistence. Circulation 1998;97:2213-2221.

79 Leander K, Wiman B, Hallqvist J, Sten-Linder M, de Faire U. Stockholm Heart Epidemiology Program. PAI-1 level and the PAI-1 4G/5G polymorphism in relation to risk of non-fatal myocardial infarction: results from the Stockholm Heart Epidemiology Program (SHEEP). Thromb Haemost 2003;89:1064-1071.

80 Huber K, Jorg M, Probst P, Schuster E, Lang I, Kaindl F, Binder BR. A decrease in plasminogen activator inhibitor-1 activity after successful percutaneous transluminal coronary angioplasty is associated with a significantly reduced risk for coronary restenosis. Thromb Haemost 1992;67:209-213.
81 Sakata K, Miura F, Sugino H, Shinobe M, Shirotani M, Yoshida H, Mori N, Hoshino T, Takada A. Impaired fibrinolysis early after percutaneous transluminal coronary angioplasty is associated with restenosis. Am Heart J 1996;131:1-6.

82 Gottsauner-Wolf M, Sochor H, Hornykewycz S, Beckmann R, Lang I, Probst P, Binder BR, Huber $\mathrm{K}$. Predictive value of PAI-1 plasma activity and thallium perfusion imaging for restenosis after percutaneous transluminal angioplasty in clinically asymptomatic patients. Thromb Haemost 1999;81:522-526.

83 Fornitz GG, Nielsen P, Amtorp O, Kassis E, Abildgard U, Sloth C, Winther K, Orskov H, Dalsgard J, Husted S. Impaired fibrinolysis determines the outcome of percutaneus transluminal coronary angioplasty (PTCA). Eur J Clin Invest 2001;31:586-592.

84 Ishiwata S, Tukada T, Nakanishi S, Nishiyama S, Seki A. Postangioplasty restenosis: platelet activation and the coagulation-fibrinolysis system as possible factors in the pathogenesis of restenosis. Am Heart J 1997;133:387-392.

-85 Mlekusch W, Schillinger M, Exner M, Sabeti S, Mannhalter C, Minar E, Wagner O. Plasminogen activator inhibitor-1 and outcome after femoropopliteal angioplasty: analysis of genotype and plasma levels. Thromb Haemost 2003;90:717723.

86 Capanni M, Antonucci E, Chiarugi L, Boddi V, Abbate R, Prisco D, Giglioli C, Dabizzi RP, Margheri M, Simonetti I, Gensini GF. Impairment of early fibrinolytic activation after PTCA: a mechanism for restenosis-related clinical recurrence. Fibrinolysis \& Proteolysis 1999;13:8-14.

87 Strauss BH, Lau HK, Bowman KA, Sparkes J, Chisholm RJ, Garvey MB, Fenkell LL, Natarajan MK, Singh I, Teitel JM. Plasma urokinase antigen and plasminogen activator inhibitor-1 antigen levels predict angiographic coronary restenosis. Circulation 1999;100:1616-1622.

88 Schneiderman J, Sawdey MS, Keeton MR, Bordin GM, Bernstein EF, Dilley RB, Loskutoff DJ. Increased type 1 plasminogen activator inhibitor gene expression in atherosclerotic human arteries. Proc Natl Acad Sci USA 1992;89:6998-7002.

89 Lupu F, Bergonzelli GE, Heim DA, Cousin E, Genton CY, Bachmann F,Kruithof EKO. Localization and production of plasminogen activator inhibitor-1in human healthy and atherosclerotic arteries. Arterioscler Thromb 1993;13:10901100.

90 Chomiki N, Henry M, Alessi MC, Anfosso F, Juhan-Vague I. Plasminogen activator inhibitor-1 expression in human liver and healthy or atherosclerotic vessel walls. Thromb Haemost 1994;72: 44-53.

91 Sobel BE, Woodcock-Mitchell J, Schneider DJ, Holt RE, Marutsuka K, Gold H. Increased plasminogen activator inhibitor type 1 in coronary artery atherectomy specimens from type 2 diabetic compared with nondiabetic patients: a potential factor predisposing to thrombosis and its persistence. Circulation 1998;97:2213-2221.

$\checkmark 92$ Pandolfi A, Cetrullo D, Polishuck R, Alberta MM, Calafiore A, Pellegrini G, et al. Plasminogen activator inhibitor type 1 is increased in the arterial wall of type II diabetic subjects. Arterioscler Thromb Vasc Biol 2001;21:1378-1382.

93 De Maat MP, Bladbjerg EM, Drivsholm T, BorchJohnsen K, Moller L, Jespersen J. Inflammation, thrombosis and atherosclerosis: results of the Glostrup study. J Thromb Haemost 2003;1:950957.
94 Marchesi E, Martignoni A, Tinelli C, Ravetta V, Resasco T, Piredda M, Defrancisci A, Finardi G, Perani G. Plasminogen activator inhibitor-1 and carotid intima-media thickening in patients with newly detected primary hypertension. J Cardiovasc Risk 1999;6:363-369.

95 Folsom AR, Pankow JS, Williams RR, Evans GW, Province MA, Eckfeldt JH. Fibrinogen, plasminogen activator inhibitor-1, and carotid intima-media wall thickness in the NHLBI Family Heart Study. Thromb Haemost 1998;79:400-404.

96 Brown NJ, Agirbasli M, Vaughan DE. Comparative effect of angiotensin-converting enzyme inhibition and angiotensin II type 1 receptor antagonism on plasma fibrinolytic balance in humans. Hypertension 1999;34:285-290.

97 Juhan-Vague I, Pyke SDM, Alessi MC, Jespersen J, Haverkate F, Thompson SG. Fibrinolytic factors and the risk of myocardial infarction or sudden death in patients with angina pectoris. Circulation 1996;94:2057-2063.

98 Reaven G. Syndrome X: 10 years after. Drugs 1999;58:19-20.

99 Juhan-Vague I, Alessi MC, Vague P. Increased plasma plasminogen activator inhibitor-1 levels. A possible link between insulin resistance and atherothrombosis. Diabetologia 1991;34:457-462.

100 Juhan-Vague I, Alessi MC, Mavri A, Morange PE. Plasminogen activator inhibitor-1, inflammation, obesity, insulin resistance and vascular risk. J Thromb Haemost 2003;1:1575-1579.

101 Mavri A, Stegnar M, Krebs M, Sentocnik JT, Geiger M, Binder BR. Impact of adipose tissue on plasma plasminogen activator inhibitor-1 in dieting obese women. Arterioscler Thromb Vasc Biol 1999;19:1582-1587.

102 Grant PJ. Beneficial effects of metformin on haemostasis and vascular function in man. Diabetes Metab 2003;29:6S44-52.

103 Kruszynska YT, Yu JG, Olefsky JM, Sobel BE. Effects of troglitazone on blood concentrations of plasminogen activator inhibitor 1 in patients with type 2 diabetes and in lean and obese normal subjects. Diabetes 2000;49:633-639.

104 Alessi MC, Morange P, Juhan-Vague I. Fat cell function and fibrinolysis. Horm Metab Res 2000;32:504-508.

105 Mavri A, Alessi MC, Bastelica D, Geel-Georgelin O, Fina F, Sentocnik JT, Stegnar M, Juhan-Vague I. Subcutaneous abdominal, but not femoral fat expression of plasminogen activator inhibitor-1 (PAI-1) is related to plasma PAI-1 levels and insulin resistance and decreases after weight loss. Diabetologia 2001;44:2025-2031.

106 Alessi MC, Bastelica D, Mavri A, Morange P, Berthet B, Grino M, Juhan-Vague I. Plasma PAI-1 Levels Are More Strongly Related to Liver Steatosis Than to Adipose Tissue Accumulation. Arterioscler Thromb Vasc Biol 2003;23:12621268

107 Samad F, Uysal T, Wiesbrock S, Pandey M, Hotamisligil S, Loskutoff J. Tumor necrosis factor is a key component in the obesity-linked elevation of plasminogen activator inhibitor 1. Proc Natl Acad Sci USA 1999;96:6902-6907.

108 Bastelica D, Mavri A, Verdierl M, Berthet B, Juhan-Vague I, Alessi MC. Relationships between fibrinolytic and inflammatory parameters in human adipose tissue: strong contribution of TNFalpha receptors to PAI-1 levels. Thromb Haemost 2002;88:481-487. 
109 Alessi MC, Bastelica D, Morange PE, Berthet B, Leduc I, Verdier M, et al. Plasminogen activator inhibitor-1, transforming growth factor 1 and body mass index are closely associated in human adipose tissue during morbid obesity. Diabetes 2000;49:1374-1380.

110 Festa A, D'Agostino R, Tracy RP, Haffner SM. Elevated levels of acute-phase proteins and plasminogen activator inhibitor-1 predict the development of type 2 diabetes. The Insulin Resistance Atherosclerosis Study. Diabetes 2002;51:11311117.
111 Schafer K, Fujisawa K, Konstantinides S, Loskutoff DJ. Disruption of the plasminogen activator inhibitor 1 gene reduces the adiposity and improves the metabolic profile of genetically obese and diabetic ob/ob mice. FASEB J 2001;15: 1840-1842

112 Ma L-J, Mao S-L, Taylor KL, Kanjanabuch T, Guan YF, Zhang YH, Brown NJ, Swift LL, McGuinness OP, Wasserman DH, Vaughan DE, Fogo AB. Preventionof obesity and insulin resistance in mice lacking plasminogen activator inhibitor. Diabetes 2004;53:336-346.
113 Morange PE, Lijnen HR, Alessi MC, Kopp F, Collen D, Juhan-Vague I. Influence of PAI-1 on adipose tissue growth and metabolic parameters in a murine model of diet-induced obesity. Arterioscler Thromb Vasc Biol 2000;20:11501154.

14 Lijnen HR, Maquoi E, Morange P, Voros G, Van Hoef B, Kopp F, et al. Nutritionally induced obesity is attenuated in transgenic mice overexpressing plasminogen activator inhibitor-1. Arterioscler Thromb Vasc Biol 2003;23:78-84. 